\title{
The mediating role of product planning and development on the relationship between markets strategies and export performance
}

\author{
Ahmedia Musa Mohamed Ibrahima and Mohamed Salih Yousif Ali ${ }^{\text {a* }}$
}

${ }^{a}$ Prince Sattam Bin Abdul Aziz University, Saudi Arabia

\begin{tabular}{l}
\hline C H R O N I C L E \\
\hline Article history: \\
Received October 27,2020 \\
Received in revised format \\
January, 25, 2021 \\
Accepted February 252021 \\
Available online \\
February 25 2021 \\
\hline Keywords: \\
Export performance \\
Market exploitation \\
Market exploration \\
Product planning and \\
development
\end{tabular}

\section{Introduction}

Export performance is considered a significant and vital element in determining success in business operations (Nuseir 2016). Many studies on international marketing highlight the importance of understanding the indicators or drivers of export performance to ensure strong competition and survival (Sousa et al., 2010; Karelakis et al., 2006; Sousa \& Tan 2015) Nevertheless, there is scope to conduct further research on the factors that drive SMEs' export growth (Stouraitis et al. 2017). While the literature on exporting performance has a long history, it has yet to achieve the degree of consensus required to propose exporting strategies to small firm owners (Casey \& Hamilton 2014). Currently, no framework can comprehensively explain all of the drivers of export performance (Lages, Jap, \& Griffith, 2008; Wheeler et al., 2008; Tan \& Sousa 2011). Ismail et al. (2018) called for future studies to focus more on how SMEs improve export performance, which refers to the extent to which a company implements marketing strategies to achieve its exportation goals (Cavusgil \& Zou 1994). Based on the multidimensional nature of performance we use three measures to assess SMEs' export performance in this study: financial-, strategic-, and customer-based measures. These three measures of performance either combine or bridge the divide between other objective and subjective measures or combines both of them (Beleska-Spasova, Glaister, \& Stride 2012). We believe that these three measures are the strongest success indicators of exporting operations now days. The towering competitive conditions that business organizations, particularly SMEs, are currently facing, allow them to shift from focusing solely on home markets to markets abroad, thus expanding their opportunities for growth. Consequently, SMEs should adequately comply with these changes to attain their exporting goals. However, even with the extensive literature on the application of international marketing strategies, few studies focus on exploitation and exploration marketing strategies for SMEs' export performance.

\footnotetext{
* Corresponding author

E-mail address: $\underline{\text { my.ali@psau.edu.sa }}$ (M. S. Y. Ali)

C 2021 by the authors; licensee Growing Science. doi: $10.5267 /$ j.uscm.2021.2.009
} 
Kyriakopoulos and Moorman (2004) abstracted that the basic problems many firms face are due to insufficient exploitation to maintain their existing viability and insufficient exploration to preserve their future viability. Few studies have investigated SMEs' exportation activities that incorporate exploration and exploitation marketing strategies, product development, and customers-based measures (Aspara et al., 2011); some exceptions include Hughes et al. (2010) and Lisboa et al. (2011). Recently, some studies have attempted to further investigate exploration and exploitation strategies to achieve competitive advantages and thus, improve management, develop international business, and advance marketing knowledge (Fletcher-Chen et al., 2017; Abebe \& Angriawan, 2014; Lu Jin et al., 2016; Dayan et al., 2016; Eltantawy, 2016).

To the best of our knowledge, this is the first empirical study to investigate this concept in Saudi Arabia, particularly in SMEs. Market exploitation strategies (METS) are defined as strategies that primarily entail improving and refining existing skills and procedures associated with existing marketing strategies, including market segments, positioning, distribution, and other marketing mix strategies (Kyriakopoulos and Moorman 2004). Market exploration strategies (MERS) are defined as strategies that primarily challenge prior approaches to interfacing with markets, such as new segmentation, new positioning, new products, new channels, and other marketing mix strategies (Kyriakopoulos \& Moorman, 2004). MERS refer to the processes that facilitate experimentation and expose modern ideas, new abilities, and novel solutions in the export markets' environment. METS refer to the processes required to apply ideas, cultivate abilities, and apply solutions in the export markets' environment.

Bahadir, Bharadwaj and Srivastava (2015) abstracted that, due to the diverse nature of markets, marketing of products globally is challenging. Product planning and development (PPD) is necessary owing to the fluctuations in product demand, swing supplies of product inputs, product-life cycles (which are increasingly becoming shorter), difficulty in changing product designs and packaging, and speedy changes in technology. Product development becomes problematic, more so while considering the diverse customer preferences across countries (Uner et al., 2013). PPD is also necessary to face the changes in external and internal export market conditions.

In this study, PPD is an intermediary dimension used to assess exporting performance; it encompasses plans to develop products, and slight mandatory and discretionary changes to current products. Further, it includes the creation of new commodities that help SME firms to comply with restrictions in foreign markets and obtain remunerative opportunities economically, satisfy customers, and guarantee success in foreign markets.

Other than acquired knowledge, firms demand skills that pertain to SMEs, which include PPD, as well as exploitative and explorative abilities that match present and future markets' needs flexibly. This study aims to contribute to the literature on the two market strategies - export performance and PPD - by evaluating and measuring the empirical conceptual framework that connects these concepts simultaneously. Accordingly, this study's major research questions are:

(1) What performance opportunities can Saudi Arabian SMEs gain from implementing exploitation and exploration strategies in foreign markets?

(2) To what extent does PPD mediate the relationship between market strategies (METS, MERS) and SMEs' export performance?

In an attempt to avoid misleading findings, we included some control variables, such as SME age and experience, in this study's model. The existing literature on exportation specifies these control variables as determinants of a company's performance.

We organize the rest of this paper as follows: In the following section, we discuss the study topic based on the organizational learning theory (OLT) and strategic fit theory (SFT). Then, we discuss the literature review, in which we explore and develop the study's framework, based on the OLT and SFT, and subsequently, derive the proposed hypotheses. Next, we discuss the methods and findings, followed by a conclusion, in which we discuss the findings, social and managerial implications, limitations, and the directions for future studies.

\section{Literature review}

\subsection{The OLT and SFT Support}

No single theory seems adequate in addressing the complexity of export marketing (Chen, Sousa, \& He, 2016). The OLT provides a theoretical foundation to illustrate how export firms shape their long-term competitive advantages, and how they experience radical changes in their export performance over time (Chen, Sousa, \& He, 2016). Learning at the firm level enables them to integrate information from their previous successes and mistakes with information from their current environment (Gabrielsson, Gabrielsson, and Seppälä 2012). The OLT provides a sound theoretical lens from which to examine firm activities that pertain to knowledge development and formulation of exploitation and exploration strategies (March 1991). It refers to the managerial understanding of the causal linkages between organizational actions and outcomes, within the environments in which firms operate (Lages, Jap, \& Griffith, 2008). The ability to learn leads to the exploration, exploitation, and development of international processes. The OLT specifies the encoding mechanism between previous organizational operations and the organization's future behavior and outcomes (Wei et al., 2014; Santos-Vijande et al., 2012). Thus, knowledge obtained through exploration and exploitation activities boosts decisions regarding future 
marketing strategies and exporting performance. The learning concept enables continuous improvement and innovation (Lages, Silva \& Styles, 2009) and helps firms to reconfigure resources and capabilities to compete successfully in international markets (Vahlne \& Johanson 2017). Learning is key for sustainable advantages and performance, particularly among SMEs (Juhdi, Hong, and Juhdi 2015). This study postulates that organizations can learn how to select markets, and plan to develop products through market forecasting from the experiences of previous managerial processes. From a learning-by-exporting perspective, new knowledge is useful in making a firm more innovative and, subsequently, exhibit superior performance (Xie \& Li, 2018). By facilitating the acquisition of new skills as well as by upgrading and strengthening prior knowledge, learning by exploitation and exploration improves PPD and makes possible the adaptation of economies of scale features that improve the performance of marketing strategies.

We based this study's second theoretical perspective on SFT. Numerous scholars have emphasized the importance and the increasing use of SFT in marketing strategies and export researches worldwide (Chen, Sousa, \& He 2016; Bahadir, Bharadwaj, \& Srivastava, 2015; Hultman, Robson \& Katsikeas 2009; Katsikeas, Samiee \& Theodosiou 2006). Westjohn and Magnusson (2017) posited that SFT predicts a positive relationship between exploration and performance. Earlier, Venkatraman and Prescott (1990) proposed that the adequacy between strategies and their contexts has significant and positive implications for performance. Thus, based on the SFT, firms apply new kinds of capabilities when managing future processes, and foster current situations through market exploration and exploitation strategies. PPD achieves a fit between MERS, METS, and the subsequent export performance. These arguments imply that SMEs cannot upgrade their export performance value unless they build or create a fit between export markets strategies and PPD. In environments where market strategies are implemented, the performance is governed by the level of PPD. Therefore, the success and fitness of a certain market strategy is largely dependent on PPD.

\subsection{Hypotheses Development}

Markets may accept or reject new products and, hence, shape firms' sustainability and success (Bonner and Walker 2004). Some studies have found that excelling at both exploitation and exploration strategies is vital for successful product development (Sheremata 2000) and long-term performance (Tushman \& O'Reilly 1996). The ideas derived from MERS and METS can be applied to PPD. He and Wong (2004) found that exploration and exploitation strategies significantly influence product innovation, while Shi et al. (2020) found that these strategies have stronger influences on firm performance in R\&D contexts, compared to other circumstances. Exploration strategies enable firms to develop new products, whereas exploitation strategies allow firms to update existing products (Bandeira-de-mello et al. 2016). Without an appropriate marketing strategy, even advanced technological products may fail to become popular (Ernst 2002). Thus, fast, unexpected, and imperative market changes may be required to implement exploration and exploitation strategies for PPD or for the responding capacity to adapt to customer needs. From the mentioned arguments, we propose hypothesis one as follows:

H1.1: Market exploitation strategy of SMEs is positively related to PPD.

$\mathbf{H}_{1.2:}$ Market exploration strategy of SMEs is positively related to PPD.

Separating firm's exploitation and exploration marketing strategies can enhance the understanding of how market orientation influences a firm's ability to explore and exploit knowledge and skills (Kyriakopoulos and Moorman 2004). Due to increased international competition, it is important for firms to develop and implement successful strategies to ensure satisfactory export performance outcomes (Laufs \& Schwens 2014; Casey \& Hamilton 2014). Shi et al. (2020) demonstrated that exploration and exploitation boost, and lead to better firm performance (Lin, Yang \& Demirkan 2007). Exploration can help firms anticipate market trends and capitalize on market opportunities, this resulting in long-term profits (Shi et al. 2020). Exploitation strategies increase efficiency, reduce periods without sales, and increase the reliability or precision of all activities (Tamayo-Torres et al., 2011), which is expected to provide companies with high and safe returns (GuisadoGonzález et al. 2017). Exploration strategies help firms develop new cognitive frames (Chiva et al., 2010), enable learning from failures (Madsen \& Desai, 2010; Edmondson, 2011), and are essential in achieving sustained competitive advantages (March 1991). The ability of an organization to maintain focus on both exploration and exploitation activities, to survive and excel in the present, and secure the future, leads to performance ambidexterity (Sinha, 2015). Exploration and exploitation strategies have the potential to enhance organizational performance (Martini et al., 2013). Therefore, we propose a second hypothesis:

H2.1: Market exploitation strategy of SMEs is positively related to (a) export strategic performance (ESP), (b) export financial performance (EFP), and (c) export customer performance (ECP).

$\mathbf{H}_{2.2}$ : Market exploration strategy of SMEs is positively related to (a) ESP (b) EFP and (c) ECP.

Developing products and processes benefit firms in several ways, such as enhancing productivity and increasing performance (Haddoud et al., 2018). Fuchs and Köstner (2016) found that the adaptation of products to market-specific characteristics has a positive effect on export success, leading to sales growth, profitability, goal achievement, and the overall success of an export venture. Calantone et al. (2004) found a positive association between the level of product adaptation and its profitability at the project level. Further, Cho and Pucik (2005) found that firm innovativeness leads to 
its profitability and growth. The discretionary adaptation of products has a positive effect on export performance (Westjohn and Magnusson 2017). In addition, product-planning aims at an optimal mixture of the product features offered, which helps a firm meet diverse customer needs and obtain competitive advantages (Miao et al. 2017). Thus, PPD facilitates product designs; simplifies customization of product lines, while maintaining the current ones; minimizes the production time, which results in reduction of operational costs; and strategically meets the target customers' needs and wants. Syamil et al. (2004) assumed a direct link between product concepts and customer satisfaction. Overall, product quality and product design and style were shown to have significant positive effects on export performance (Leonidoua, Katsikeasb, \& Samiee 2002). Utilizing PPD to differentiate products, develop existing products, or launch new product for target customers leads to economically successful products/services that are valued by customers, and ensures quick compliance with required mandatory terms. From the above-mentioned arguments, we propose hypothesis three:

\section{$\mathbf{H}_{3}: P P D$ in SMEs is positively related to (a) ESP, (b) EFP, and (c) ECP.}

Product development and exploitation and exploration strategies for overseas market represent a combined group of skills that are rooted in exporting firm's procedures and that can achieve competitive advantages, based on the superior offerings (Day 1994; Hult \& Ketchen, 2001). Product planning involves determining the number of product variants and their design attribute settings (Aydin, Kwong, \& Ji, 2016). PPD may identify the target markets' demand trends, foresee changes in customers' needs, and better address international business opportunities and threats. These changes occur systematically in the products' planning and developing processes. Without an effective exploitation and commercialization strategy, efforts to develop new technical products will be futile (Lettice, Roth, \& Forstenlechner, 2006). Based on the exploration and exploitation strategies for overseas markets, firms can adopt an organized approach to gauge markets' competitive degrees, determine exporting opportunities, and subsequently plan to develop products that lead to superior performance. PPD is important in meeting new or emerging customer needs and preferences, or in meeting their existing needs and wants in current and target markets. PPD maintains the export products' characteristics in worldwide markets and satisfying most customer needs. To meet the minimum product requirements, which vary by country, a proactive PPD is required. Zou and Stan, (1998) identified product strategy as one of the key factors for measuring export performance, based on the export marketing strategy. Firm's product characteristics influence their export marketing strategies (Cavusgil \& Zou, 1994). Export marketing strategy is influenced by internal firm's product characteristics

Lisboa et al. (2011) posit that product development, based on exploitative and explorative capabilities in overseas markets, can result in new product differentiation advantages, which, in turn, can influence market effectiveness. Companies in highly dynamic markets increasingly struggle with planning product development and creating reliable roadmaps that utilize new approaches to cope with their conditions (Münch et al. 2019). Loch et al. (1996) have emphasized that assessing product development performance is vital to understand the important drivers of performance outputs (Lettice et al. 2006). To remain competitive, firms need to engage in exploitative and explorative activities, not only in the product development context, but also in the marketplace (Lisboa et al. 2011). Market exploration and exploitation strategies lead to effective export performance, particularly when firms concurrently introduce PPD. Consequently, in this study, we propose that explorative and exploitative market strategies have an effect on SMEs' performance, through the mediating role of PPD. Therefore, we propose the fourth hypothesis as follows:

H4.1: PPD in SMEs mediates the relationship between METS and (a) ESP, (b) EFP, and (c) ECP.
$\mathbf{H}_{4.2}$ : PPD in SMEs mediates the relationship between MERS and (a) ESP, (b) EFP, and (c) ECP.

We control factors that may affect SME's performance, and minimize their effects on the main variables of this study model. These factors include a) ownership of a company; b) age of a company; c) number of employees; d) international export experience; e) annual sales; f) types of products; and g) number of target markets.

\section{Materials and methods}

We based this study on a quantitative methodological prospective and gathered primary data to investigate the hypotheses mentioned above. We conducted a survey using electronic questionnaires, in which we sent e-mail messages to key informants, whom we anticipated were top managers or were engaged in decisions regarding product exportations as well as exploration and exploitation activities. In the questionnaire, we explained the purpose of the study and mentioned that participation was voluntarily. Further, the email invitation message includes paragraph that show SMEs' managers to be confidence to participate in this survey and remove their fear of seeping their business information. Thereafter, we invited the respondents to fill in the online questionnaires, and provided a link at the end of the message.

We designed the questionnaire following Huber and Power's (1985) guidelines to fit the respondents. We sent the questionnaire items in Arabic, accompanied by English translations, which three bilingual academics had prepared to ensure clarity and reduce loss of meaning. The questionnaire contained two-part questions. The first part included several SMEs' demographic characteristics, which we used as control variables. The second part included six main dimensions of this study. All items measured in part two of the questionnaire were assessed based on a seven-point Likert scale, ranging from (1) strongly disagree to (7) strongly agree. 
We based this study's conceptual framework on the OLT and SFT and used an SME as a unit of analysis, on which we requested respondents to comment. Cavusgil and Zou (1994) maintain that the proper unit of analysis in export performance research should be the export venture. We used several goodness-of-fit techniques, such as the AMOS 25 and SPSS 25 statistical packages to analyze the study's data.

\subsection{Data Collection and Sampling}

We collected data between December 29, 2019 and February 27, 2020, in Saudi Arabia, which we consider a growing economy. We obtained contact data for more than 1500 SMEs from the Chamber of Commerce of the Saudi Ministry of Commerce database. All SMEs services firms were excluded from the study population due to the nature of the study that focused on industrial and consumer goods of SMEs exporting firms, as well as the SMEs whose their contact information was not active after a primary check we used. Thereafter, we explored 538 effective communication data, and qualified SMEs that fit study's nature, which then formed this study's sample. We randomly sent this survey to SMEs in Saudi Arabia. Thereafter, we sent two reminders through emails after the first three weeks to increase the response rate. Of this sample, 125 SMEs filled in the electronic questionnaires, resulting in 122 valid questionnaires, which was approximately a $23 \%$ response rate. We deemed this response rate as completely acceptable, given that top management response rates in surveys average between 15\%-20\% (Menon et al., 1999). Table 1 shows the SMEs' profile characteristics. In the sample, $81.97 \%$ of SME ownerships were partnerships, $15.57 \%$ were sole proprietorships, and $2.46 \%$ were private corporations. Regarding the SMEs' age, $48.36 \%$ were 12 years old or more, $35.24 \%$ were $9-11$ years old, $10.66 \%$ were $6-8$ years old, $3.28 \%$ were 3-5 years old, and $2.46 \%$ were less than 3 years old. Additionally, more than half, $58.20 \%$, of the SMES had more than 50 full-time employees, classified as medium-sized SMEs; $41.80 \%$ had less than 50 full-time employees, classified as small SMEs. Regarding SMEs' international experiences, $66.39 \%$ had more than seven years of experience, $29.50 \%$ had from 4 6 years, and $4.10 \%$ had from 1-3 years. Furthermore, $47.50 \%$ of SMEs had annual sales in the range of 450,000-649,999 dollars; $23.80 \%$ from $250,000-449,999,21.30 \%$ from $650,000-849,999$, and $7.40 \%$ less than 250,000 dollars. A majority $(81.10 \%)$ of the SME products was consumer products and $18.90 \%$ was industrial products. Lastly, $59 \%$ of the SMEs had 3-6 target markets and $41.00 \%$ had $1-3$ target markets.

Table 1

SMES characteristics' profile

\begin{tabular}{|c|c|c|c|c|c|}
\hline \multirow{2}{*}{$\begin{array}{l}\text { Ownership of SME } \\
\text { Frequency }\end{array}$} & \multirow{2}{*}{$\begin{array}{c}\text { Sole proprietorship } \\
19\end{array}$} & \multirow{2}{*}{$\begin{array}{c}\text { Partnership } \\
100\end{array}$} & \multirow{2}{*}{$\begin{array}{c}\begin{array}{c}\text { Private } \\
\text { Corporation }\end{array} \\
3\end{array}$} & \multicolumn{2}{|c|}{ Other } \\
\hline & & & & & \\
\hline percentage & $15.57 \%$ & $81.97 \%$ & $2.46 \%$ & & \\
\hline Age of SME & Less than 3 years & $3-5$ & 6-8 & 9-11 & $12+$ \\
\hline Frequency & 3 & 4 & 13 & 43 & 59 \\
\hline percentage & $2.46 \%$ & $3.28 \%$ & $10.66 \%$ & $35.24 \%$ & $48.36 \%$ \\
\hline Number of employees & Less than 10 & $10-49$ & & $\mathbf{5 0 +}$ & \\
\hline Frequency & 1 & 50 & & 71 & \\
\hline percentage & $.80 \%$ & $41.00 \%$ & & $58.20 \%$ & \\
\hline International export experience & 1-3 years & 4-6 years & & $7+$ years & \\
\hline Frequency & 5 & 36 & & 81 & \\
\hline percentage & $4.10 \%$ & $29.50 \%$ & & $66.39 \%$ & \\
\hline $\begin{array}{l}\text { Annual sales in dollar ( } 1 \text { dollar } \approx \\
3.75)\end{array}$ & Less than 250,000 & $250,000-449,999$ & $\begin{array}{c}450,000- \\
649,999\end{array}$ & $\begin{array}{l}650,000- \\
849,999\end{array}$ & $850,000+$ \\
\hline Frequency & 9 & 29 & 58 & 26 & \\
\hline percentage & $7.40 \%$ & $23.80 \%$ & $47.50 \%$ & $21.30 \%$ & \\
\hline Products types & Consumer products & Industrial products & Both & & \\
\hline Frequency & 99 & 23 & & - & \\
\hline percentage & $81.10 \%$ & $18.90 \%$ & & - & \\
\hline Number of target markets & $1-3$ & 4-9 & & $10+$ & \\
\hline Frequency & 50 & 72 & & - & \\
\hline percentage & $41.00 \%$ & $59.00 \%$ & & - & \\
\hline
\end{tabular}

\subsection{Nonresponse Bias and Common Method Bias (CMB) Tests}

In this study, we followed Armstrong and Overton (1977) guidelines to test for non-response bias. First, we considered SMEs that responded in three weeks as earlier respondents, and those that responded after the e-mail reminders as late respondents, representing $65 \%$ and $35 \%$ respectively. Further, T-test results did not indicate significant statistical differences between earlier and late responses observed. Thus, the nonresponse bias did not affect this study. Further, we conducted several investigations to test CMB. For instance, we conducted Harman's one-factor test, following the guidelines set by Podsakoff et al. (2003). As shown in Table 2, the accumulated variance explains (78.93\%) of the distribution between the factors. The first factor variance explained is (19.69\%), with eigenvalue (7.28), which proves that this is not the controlling factor. Therefore, this study's data set is free from CMB. Further, we assessed the existence of CMB using VIFs of latent variables. This model met the frequently recommended threshold criterions: the highest VIFs score value is 1.493 and the lowest tolerance value is .370 . Hence, CMB is unlikely to be a threat. Furthermore, considering the content validity and the inverse items of measure in the questionnaire together also reduced the risk of CMB. 
We developed this study's scale following Rossiter (2002) and the recommendations by Nunnally and Bernstein's (1994) for new model development (Lisboa et al., 2011). Further, we made some slight modifications or changes to the items of measure to match the context of the SMEs, which we adopted from previous, well-validated and developed research measures. We measured the SMEs' METS and MERS using nine and eight items, respectively (Lisboa et al., 2011; de Visser \& Faems, 2015; Shi et al., 2020; Kyriakopoulos \& Moorman, 2004) and measured PPD using six items (Haddoud et al., 2018; Leonidou, Palihawadana, \& Theodosiou, 2011; Lejpras, 2019). We measured EFP and ESP using four items (Haddoud et al., 2018; Zou et al., 1998; Ural, 2009; Zou \& Cavusgil, 2002) and measured ECP using five items (Hultman, Katsikeas, \& Robson 2011; Samiee \& Chirapanda 2019). Table 2 displays the measurement items.

\section{Analysis}

\subsection{The KMO and EFA Test}

As shown in Table 2, the Kaiser-Meyer-Olkin measure of sampling adequacy is .898 and the Bartlett's Test of Sphericity is 4545.583 , which fulfils the factor analysis standards. While preparing to conduct the Confirmatory-factor analysis (CFA) and determine the validity and reliability of measurements, we performed an EFA in SPSS for 36 items; no item failed this test (see Table 2). The EFA confirms that each group of indicators explains only one practice (Tamayo-Torres et al. 2011). Using the Varimax rotation process with principal component analysis (PCA), we extracted the items of measure into six factors: the Eigenvalue is greater than one, the total explained variance is $78.93 \%$, each factor Cronbach's alpha is more than .70, and their average variance extracted (AVE) is greater than the required level, which is .50. The AVEs are loaded significantly and range from .642 to .860 .

\section{Table 2}

Study's KMO and EFA analyses

\begin{tabular}{|c|c|c|c|c|c|c|}
\hline \multirow[t]{2}{*}{$\begin{array}{r}\text { Kaiser-Meyer-Olkin Measur } \\
\text { Bartlett's Test o } \\
\text { Df } \\
\text { Sig }\end{array}$} & $\begin{array}{l}\text { e of Sa } \\
\text { f Spher }\end{array}$ & ng Ade & & & \multicolumn{2}{|c|}{$\begin{array}{c}.898 \\
4545.583 \\
630 \\
.000\end{array}$} \\
\hline & .966 & .958 & .919 & .934 & .940 & .901 \\
\hline MERS2. My SME identifies prospective customers & .836 & & & & & \\
\hline MERS8. My SME acquires export market-related information about new markets. & .825 & & & & & \\
\hline MERS3. My SME assesses the potential of new markets. & .818 & & & & & \\
\hline MERS4. My SME researches new competitors and new customers. & .818 & & & & & \\
\hline MERS7. My SME builds relationships in new markets. & .811 & & & & & \\
\hline MERS5. My SME builds new overseas distributor relationships. & .777 & & & & & \\
\hline MERS9. My SME makes products difficult for competition to copy. & .773 & & & & & \\
\hline MERS1. My SME new products do have a significant advantage over those of competitors. & .736 & & & & & \\
\hline MERS6. My SME adopt entrepreneurial orientation-exploration. & .733 & & & & & \\
\hline METS7. My SME enhances the capture of important market information about existing markets. & & .860 & & & & \\
\hline METS5. My SME reinforces contacts in current export markets. & & .857 & & & & \\
\hline METS4. My SME reinforces the monitoring of competitive products in current export markets. & & .837 & & & & \\
\hline METS6. My SME enhances understanding of existing overseas customer requirements. & & .825 & & & & \\
\hline METS3. My SME reinforces relationships with current overseas customers. & & .815 & & & & \\
\hline METS8. My SME reinforces overseas distributor relationships. & & .764 & & & & \\
\hline METS1. My SME improves entrepreneurial orientation-exploitation. & & .751 & & & & \\
\hline METS2. My company improved our prior skills and procedures of markets positioning and differentiation & & .742 & & & & \\
\hline PPD6. Our SME is constantly sensing trends and competitors' products movements in overseas markets. & & & .779 & & & \\
\hline PPD4. Our SME has extensive knowledge about foreign market products demand. & & & .778 & & & \\
\hline PPD3. Our SME constantly is referring to our products plan to direct our export activities. & & & .772 & & & \\
\hline PPD2. our SME has not marketed new product in the past three years (inverse) & & & .764 & & & \\
\hline PPD1. Our structured products plan is widely disseminated throughout the organization & & & .748 & & & \\
\hline PPD5. Our SME meets foreign markets products regulations standards. & & & .665 & & & \\
\hline ECP2. Our export performance in the last 3 years increased the customer retention/loyalty. & & & & .808 & & \\
\hline ECP3. Our export performance in the last 3 years generated new customers. & & & & .804 & & \\
\hline ECP1. Our export performance in the last 3 years met the customer satisfaction. & & & & .755 & & \\
\hline ECP4. Our export performance in the last 3 years improved the customer service. & & & & .695 & & \\
\hline ECP5. Our export performance in the last 3 years run customer referral programs. & & & & 686 & & \\
\hline EFP3. Over the previous three years, this SME international business was profitable. & & & & & .837 & \\
\hline EFP2. Over the previous three years this SME company achieved rapid growth internationally & & & & & .823 & \\
\hline $\begin{array}{l}\text { EFP4. Over the previous three years, this SME return on investment (ROI) is higher than it is her major } \\
\text { competitors. }\end{array}$ & & & & & .805 & \\
\hline EFP1. Over the previous three years, this SME has generated a high volume of international sales. & & & & & .642 & \\
\hline ESP3. Over the previous three years, our company venture has improved our global competitiveness. & & & & & & .801 \\
\hline $\begin{array}{l}\text { ESP4. Over the previous three years, our company has been able to build a global leadership position in } \\
\text { our industry. }\end{array}$ & & & & & & .781 \\
\hline ESP2. Over the previous three years, our company has significantly increased our market share. & & & & & & .761 \\
\hline $\begin{array}{l}\text { ESP1. Over the previous three years, our company has strengthened our strategic position in the export } \\
\text { market. }\end{array}$ & & & & & & .672 \\
\hline Eigen values & 7.28 & 3.43 & 2.81 & 1.73 & 1.61 & 1.56 \\
\hline Variance explained & 19.69 & 18.46 & 12.45 & 10.92 & 8.86 & 8.55 \\
\hline
\end{tabular}

\subsection{The CFA Test}

We conducted CFA to ensure uni-dimensionality and as a second purification measure after EFA, through LISREL. Figure 1 and Table 3 show the indices of the study's model, that is, chi-square value (CMIN), Comparative Fit Index (CFI), 
Goodness-of-Fit Index (GFI), Incremental Fit Index (IFI), Normed Fit Index (NFI), Standardized Root-Mean-Square Residual (SRMR), and Root Mean Square Error of Approximation (RMSEA), which satisfactorily fit the acceptable threshold or exceed it. It is worth mentioning that we excluded five items from the 36 items in the CFA test to reach the model fit, due to high cross-loadings and low item-to-total correlation. Those items are PPD1, PPD2, EFP1, ESP1, and ESP4.

Table 3

Model's Measures Fit

\begin{tabular}{lllll}
\hline Measure & Estimate & Threshold & Interpretation & \\
\hline CMIN & 635.034 & -- & -- & \\
DF & 414 & -- & -- & Reference \\
CMIN/DF & 1.534 & Between 1 and 3 & Excellent & Hair et al. (2010) \\
CFI & 0.95 & $>0.90$ & Excellent & Fan et al. (1999) \\
GFI & 0.95 & $>0.95$ & Acceptable & Hu \& Bentler (1997) \\
IFI & 0.97 & $>0.90$ & Excellent & Bollen (1989) \\
NFI & 0.93 & $>0.90$ & Good & Bollen (1989) \\
SRMR & 0.058 & $<0.08$ & Excellent & Boreskog and Sorbom (2001) \\
RMSEA & 0.066 & $<0.06$ & Acceptable & Browne and Cudeck (1993) \\
\hline
\end{tabular}

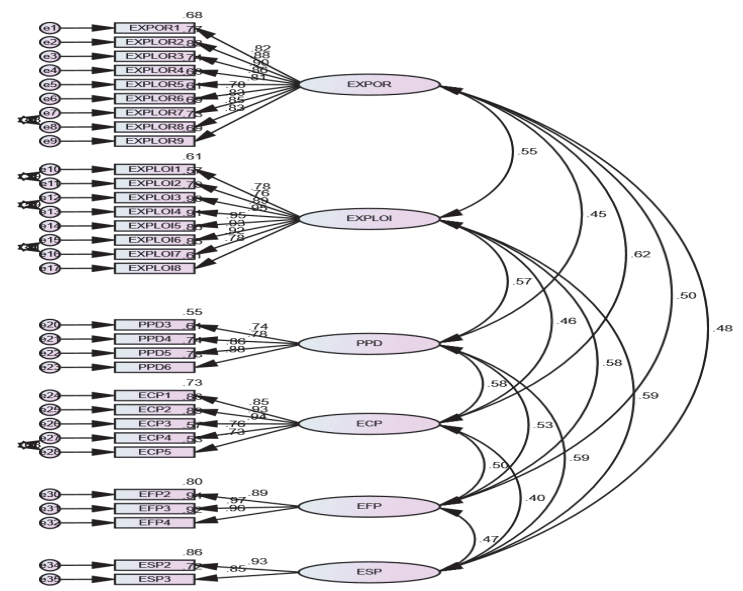

Fig. 1. The CFA test

\subsection{Validity Measures}

Five international commerce lecturers from three Saudi Arabian universities reviewed the questionnaire, based on a review of previous literature, which they used to check for content validity and consistency with the study's aims. Table 4 shows the verification of convergent validity, as assessed by Fornell and Larcker's (1981)'s procedures, which showed a composite reliability (CR) values above .70 and an average variance extracted values (AVE) above .50, indicating convergent validity. Further, the MSV values are lower than the corresponding AVE values. We verified the discriminant validity by comparing the square root of the AVE values and the square root correlation between the constructs, which indicates that the square root of the AVE values is the highest, guaranteeing discriminant validity.

Table 4

Model Validity Measures

\begin{tabular}{|c|c|c|c|c|c|c|c|c|c|c|}
\hline & $\mathrm{CR}$ & AVE & MSV & $\operatorname{MaxR}(\mathrm{H})$ & MERS & METS & PPD & ECP & EFP & ESP \\
\hline MERS & 0.956 & 0.709 & 0.381 & 0.959 & 0.842 & & & & & \\
\hline METS & 0.962 & 0.764 & 0.35 & 0.975 & $0.554 * * *$ & 0.874 & & & & \\
\hline PPD & 0.891 & 0.672 & 0.353 & 0.903 & $0.447 * * *$ & $0.574 * * *$ & 0.819 & & & \\
\hline ECP & 0.926 & 0.718 & 0.381 & 0.951 & $0.617 * * *$ & $0.464 * * *$ & $0.581 * * *$ & 0.847 & & \\
\hline EFP & 0.96 & 0.888 & 0.333 & 0.97 & $0.497 * * *$ & $0.577 * * *$ & $0.527 * * *$ & $0.501 * * *$ & 0.942 & \\
\hline ESP & 0.882 & 0.789 & 0.353 & 0.895 & $0.478 * * *$ & $0.592 * * *$ & $0.594 * * *$ & $0.398 * * *$ & $0.470 * * *$ & 0.888 \\
\hline
\end{tabular}

$\overline{* * *} \mathrm{P}<0.001$

\subsection{Descriptive Statistics and Correlations}

Table 5 shows the Pearson's correlations, arithmetic means, and standard deviations of market exploration strategies (MERS), market exploitation strategies (METS), product planning and development (PPD), export strategic performance (ESP), export financial performance (EFP), and export customer performance (ECP) dimensions that we utilized in the study model. The findings indicate that SMEs in Saudi Arabia focus more on ECP (mean=3.88, standard deviation=.97441), 
followed by ESP (mean=3.61, standard deviation=.82349), EFP (mean=3.25, standard deviation=.86938), MERS (mean=3.09, standard deviation=.67258), PPD (mean=3.01, standard deviation=.61937), and METS (mean=2.80, standard deviation=.74480). Additionally, the inter-correlations between the variables are stronger and positive at a significance level of $\mathrm{p}$-value $=.01(2$-tailed $)$, which helped conduct the regression analysis.

Table 5

Descriptive Statistics and Correlations $(\mathrm{N}=122)$

\begin{tabular}{|c|c|c|c|c|c|c|c|c|}
\hline & Mean & Std. Deviation & ESP & EFP & ECP & PPD & METS & MERS \\
\hline ESP & 3.61 & .82349 & 1 & & & & & \\
\hline EFP & 3.25 & .86938 & $.501^{* *}$ & 1 & & & & \\
\hline ECP & 3.88 & .97441 & $.430^{* *}$ & $.521^{* *}$ & 1 & & & \\
\hline PPD & 3.01 & .61937 & $.648^{* *}$ & $.559^{* *}$ & $.620^{* *}$ & 1 & & \\
\hline METS & 2.80 & .74480 & $.630^{* *}$ & $.595^{* *}$ & $.484^{* *}$ & $.610^{* *}$ & 1 & \\
\hline MERS & 3.09 & .67258 & $.512^{* *}$ & $.515^{* *}$ & $.645^{* *}$ & $.479^{* *}$ & $.574^{* *}$ & 1 \\
\hline
\end{tabular}

**. Correlation is significant at the 0.01 level (2-tailed).

\subsection{Hypotheses Testing}

Fig. 2 shows the estimation results of the structural model. The goodness of fit indices are $\chi 2=(4.617), \mathrm{DF}=3, \mathrm{CMIN} / \mathrm{DF}=$ 1.539 with $\mathrm{RMSEA}=0.067, \mathrm{NFI}=0.98, \mathrm{CFI}=0.99, \mathrm{IFI}=0.99, \mathrm{GFI}=0.98$, and $\mathrm{SRMR}=0.017$, which suggest an acceptable model fit, as long as it exceeds the usual indicators of model acceptance by researchers. After exceeding the limit values of the suitability indicators, which we considered acceptable, we tested the model relationships using the SEM method. Path relationships in Table 6 support H1.1 and H1.2 $(\beta=.415, \mathrm{p}=.000$ and $\beta=.177, \mathrm{p}=.037$, respectively); H2.1a and H2.1b are also supported $(\beta=.353, p=.000$ and $\beta=.341, p=.000$, respectively); are also supported $(\beta=.353, p=.000$ and $\beta=$ $.341, \mathrm{p}=.000$, respectively); however, H2.1 c is not supported $(\beta=-.056, \mathrm{p}=.623)$. H2.2a, H2.2b and H2.2c are supported $(\beta=.213, p=.034, \beta=.212, p=.058$, and $\beta=.686, p=.000$, respectively), and H3a, H3b and H3c are supported ( $\beta=.519$, $p=.000, \beta=.402, p=.000$ and $\beta=.670, p=.000$, respectively). In addition, the seven control variables' paths influence with ESP, EFP, and ECP were not supported, except for ownership of a company with ECP $(\beta=.315, p=.078)$ and annual sales with $\operatorname{EFP}(\beta=.181, p=.094)$, at the .10 level of significant.

\section{Table 6}

Regression Weights: (Group number 1 - Default model)

\begin{tabular}{|c|c|c|c|c|c|c|c|}
\hline & & & Estimate & S.E. & C.R. & $\mathrm{P}$ & Label \\
\hline PPD & $\leftarrow$ & METS & .415 & .072 & 5.783 & $* * *$ & par 23 \\
\hline PPD & $\leftarrow$ & MERS & .177 & .079 & 2.232 & .026 & par_24 \\
\hline ESP & $\leftarrow$ & METS & .353 & .099 & 3.558 & $* * *$ & par_25 \\
\hline EFP & $\leftarrow$ & METS & .341 & .111 & 3.088 & .002 & par_26 \\
\hline ECP & $\leftarrow$ & METS & -.056 & .114 & -.491 & .623 & par_27 \\
\hline ESP & $\leftarrow$ & MERS & .213 & .100 & 2.125 & .034 & par_28 \\
\hline EFP & $\leftarrow$ & MERS & .212 & .112 & 1.895 & .058 & par_29 \\
\hline ECP & $\leftarrow$ & MERS & .686 & .116 & 5.935 & $* * *$ & par_30 \\
\hline ESP & $\leftarrow$ & PPD & .519 & .109 & 4.764 & $* * *$ & par_31 \\
\hline EFP & $\leftarrow$ & PPD & .402 & .122 & 3.308 & $* * *$ & par_32 \\
\hline ECP & $\leftarrow$ & PPD & .670 & .125 & 5.348 & $* * *$ & par_33 \\
\hline ECP & $\leftarrow$ & ownership of a company & .315 & .178 & 1.763 & .078 & par_37 \\
\hline EFP & $\leftarrow$ & ownership of a company & -.200 & .173 & -1.157 & .247 & par_38 \\
\hline ESP & $\leftarrow$ & ownership of a company & -.024 & .155 & -.156 & .876 & par_39 \\
\hline ECP & $\leftarrow$ & age of a company & .009 & .078 & .117 & .907 & par_40 \\
\hline EFP & $\leftarrow$ & age of a company & .092 & .075 & 1.213 & .225 & par_41 \\
\hline ESP & $\leftarrow$ & age of a company & -.018 & .068 & -.264 & .792 & par_42 \\
\hline ECP & $\leftarrow$ & number of employees & .014 & .122 & .117 & .907 & par_43 \\
\hline EFP & $\leftarrow$ & number of employees & -.093 & .118 & -.788 & .430 & par_44 \\
\hline ESP & $\leftarrow$ & number of employees & .142 & .106 & 1.335 & .182 & par_45 \\
\hline ECP & $\leftarrow$ & international export experience & .087 & .113 & .770 & .441 & par_46 \\
\hline EFP & $\leftarrow$ & international export experience & .157 & .110 & 1.427 & .154 & par_47 \\
\hline ESP & $\leftarrow$ & international export experience & .035 & .099 & .359 & .720 & par_48 \\
\hline ECP & $\leftarrow$ & annual sales & -.084 & .111 & -.751 & .453 & par_49 \\
\hline EFP & $\leftarrow$ & annual sales & .181 & .108 & 1.677 & .094 & par_50 \\
\hline ESP & $\leftarrow$ & annual sales & -.054 & .097 & -.553 & .580 & par_51 \\
\hline ECP & $\leftarrow$ & types of products & -.021 & .165 & -.128 & .898 & par_52 \\
\hline EFP & $\leftarrow$ & types of products & .088 & .160 & .550 & .582 & par_53 \\
\hline ESP & $\leftarrow$ & types of products & .047 & .143 & .329 & .742 & par_54 \\
\hline ECP & $\leftarrow$ & number of target markets & -.111 & .128 & -.869 & .385 & par_55 \\
\hline EFP & $\leftarrow$ & number of target markets & -.113 & .124 & -.910 & .363 & par_56 \\
\hline ESP & $\leftarrow$ & number of target markets & .138 & .111 & 1.242 & .214 & par_57 \\
\hline
\end{tabular}




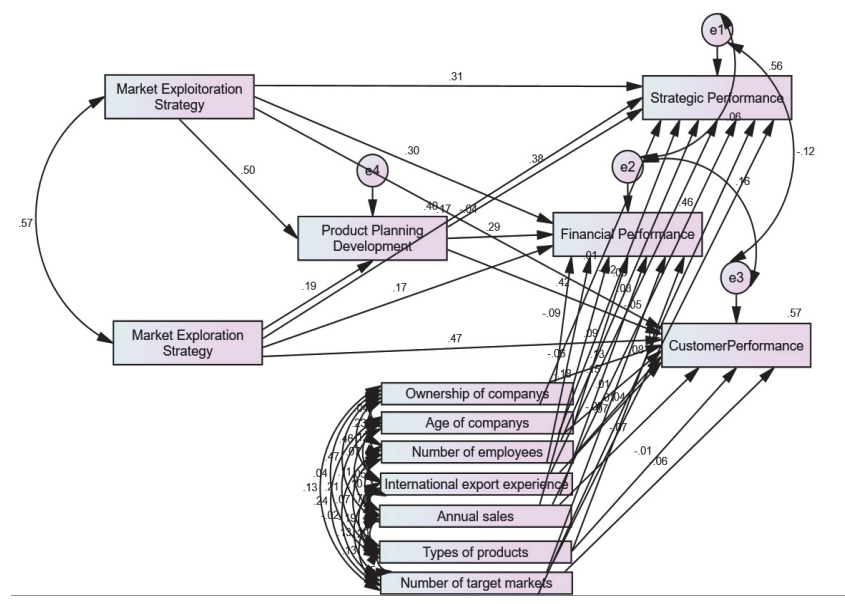

Fig. 2. Structural model with parameter estimates

\subsection{Mediation Variable Test}

Using a .05 level of significance, Table 7 presents the test results for the mediating effect, following the bootstrap approach procedure used by Preacher and Hayes (2004; 2008), Venkatraman (1990), MacKinnon et al. (2004), and Chin (2001) (indirect effects - two-tailed). The findings indicate that PPD mediates the relationship between exploration strategy and export performance (ESP and EFP) as well as the relationship between exploitation strategy and export performance (ESP, EFP, and ECP). Furthermore, H4.1a, H4.1b, H4.1c, H4.2a and H4.2b are supported; however, H4.2c is not supported. Regarding the mediating type, PPD is a partial mediator between exploitation strategy and export performance (ESP, EFP, and ECP) and between exploration strategy and export performance (ESP, EFP). A partial mediator because the direct and indirect relationships between them imply significant relations and depletions in indirect relations. Whereas the relationship between exploration strategy and ECP is not significant, on introducing PPD, the relationship becomes significant. Thus, PPD, in this case, is a complete mediator (Lisboa et al. 2011). Hence, the intervention of the PPD variable on the relationship between exploitation strategy and ECP is indispensable.

Table 7

Indirect Effects - Two Tailed Significance (BC) (Group number 1 - Default model)

\begin{tabular}{|c|c|c|c|c|c|c|c|c|c|c|}
\hline & $\begin{array}{l}\text { Annual } \\
\text { Sales }\end{array}$ & $\begin{array}{l}\text { Types of } \\
\text { products }\end{array}$ & $\begin{array}{c}\text { Ownership } \\
\text { of a } \\
\text { company }\end{array}$ & $\begin{array}{l}\text { Age of a } \\
\text { company }\end{array}$ & $\begin{array}{l}\text { Number of } \\
\text { Employees }\end{array}$ & $\begin{array}{l}\text { Number } \\
\text { of target } \\
\text { Markets }\end{array}$ & $\begin{array}{c}\text { International } \\
\text { export } \\
\text { experience }\end{array}$ & MERS & METS & PPD \\
\hline PPD & $\cdots$ & $\cdots$ & $\ldots$ & $\cdots$ & $\cdots$ & $\ldots$ & $\ldots$ & $\cdots$ & $\cdots$ & .. \\
\hline ECP & $\ldots$ & $\ldots$ & $\ldots$ & $\ldots$ & $\ldots$ & $\ldots$ & $\ldots$ & .043 & .001 & ... \\
\hline EFP & $\ldots$ & $\ldots$ & $\cdots$ & $\cdots$ & $\ldots$ & $\ldots$ & $\ldots$ & .048 & .005 & $\cdots$ \\
\hline ESP & $\ldots$ & $\ldots$ & $\ldots$ & $\ldots$ & $\ldots$ & $\ldots$ & $\ldots$ & .063 & .001 & $\ldots$ \\
\hline
\end{tabular}

\section{Discussion}

This study aimed to develop and test a model that confirms the importance of two market strategies, using which SMEs influence export performance directly and indirectly through PPD. Additionally, it answered the main research questions; specifically, what types of export performance can Saudi Arabian SMEs achieve from implementing exploitation and exploration strategies in foreign markets? To what extent can PPD mediate between market strategies (MERS and METS) and SMEs' export performance?

Findings indicate that Saudi Arabian SMEs do not display varying marketing behaviors, compared to bigger firms. We discuss this study's findings as follows: First, the finding regarding the positive relationship between markets' exploitation and exploration, and the export performance (strategic, financial, customer), is consistent with previous research. This indicates that a strategic allocation of exploitation and exploration strategies positively affects different aspects of firms' performance (Shi et al., 2020; Uotila et al., 2009; Jansen, Van Den Bosch, \& Volberda 2006; He \& Wong 2004). Katsikeas, Samiee, and Theodosiou (2006) indicated that the contingency between export strategies and the marketing environment determines export success. Further, Leonidou, Palihawadana, and Theodosiou (2011) found that a firm's export market performance has a positive impact on its export financial performance. Second, we discuss the significance of the relationship between MERS, METS, and PPD. The SMEs' ability to explore and exploit, constitute significant exporting and learning mechanisms that enable knowledge acquisition that can help overcome market difficulties, meet products' design requirements, and avail market opportunities. Third, success in PPD positively and significantly influences SMEs' 
performance. To benefit from export market opportunities, a firm must activate PPD. Uner et al. (2013) support this result, as they found that developing products is a major concern for committed exporter firms. In addition, for a company to perform better in international markets, it should maintain good product strategies. Faruk and Subudhi (2019) and Lukas et al. (2007) asserted that there is a positive relationship between export planning and export performance. Fourth, PPD mediates the relationship between METS and ESP, between EFP, and ECP, and between MERS, EFP, and ECP. These findings are consistent with the literature in that a strong connection exists between the structure of product development and market outcomes (Bala, Krishnan, and Zhu 2013). Finally, PPD does not mediate the relationship between MERS and ESP. The possible explanation for this is that minor product modifications and incremental product improvements are insufficient for distinguishing a firm's product from those of their competitors (Song and Parry 1997). Furthermore, the literature suggests that firms set goals to achieve strategic outcomes, which relate to the future, rather than immediate, financial returns (Freeman, Styles, and Lawley 2012).

\section{Conclusion, implication, limitation and scope}

\subsection{Conclusion}

In this study, we developed a composite and coherent scale model, based on OLT and SFT, which focuses on two substantial marketing strategies (exploration and exploitation) and PPD, as well as their influence on exporting performance. We clarified the relationship between MERS, METS, and SMEs' export performance. Exploration and exploitation strategies play substantial roles in grasping the various behaviors that SMEs exhibit when they evolve their marketing abilities and achieve their objectives. MERS and METS enable SMEs to identify opportunities or competition levels, closely follow up on foreign markets' movements, and better counter these movements. Further, this study determines the indirect influences that are necessary for PPD to have a significant impact on SMEs' export performance. PPD provides an applied mechanism to successfully utilize other marketing mix elements and innovatively manage changes in markets. This study establishes an additional solid ground for SMEs to expand their international operations.

\subsection{Study Implications}

This study has some significant implications. By scouting the influence of exploration and exploitation strategies on SMEs' export performance, the study sheds light on the significance of implementing both exploration and exploitation strategies for SMEs exporting to foreign markets. Exploitation and exploration strategies are the two driving forces in performance ambidexterity. In an internationalizing process, firms with previous experience from specific markets can apply these experiences and thus, expand to new foreign markets. Moreover, this study's findings contribute to the literature discussing the valuable role of the mediation effect of PPD on the relationship between exploration and exploitation marketing strategies and export performance. Subsequently, these findings progress international exporting processes and provide valuable guidance for policy makers and SME managers to strengthen foreign markets' opportunities. Further, to fit the conditions in foreign markets, SMEs should incorporate both strategies. The findings have implications for SME management teams that intend to compete through foreign marketing strategies and product development. SMEs can achieve their paramount objectives and exist in a wide number of constantly profitable foreign markets by acquiring essential exploration skills and exploitation experiences, which qualify them to implement their marketing' strategies effectively. Managers should link PPD with MERS and METS for export performance growth. Further, SME managements should be conscious about the synchronous benefits of applying markets' exploitation and exploration strategies to their export performance. Finally, management should consider adopting exploration and exploitation strategies as important entrepreneurial options for improving export performance.

\subsection{Limitation and Direction of Future Studies}

A key limitation of this study is that the sample comprises SMEs operating in Saudi Arabia. Thus, the study's findings may be specific to Saudi Arabian SMEs. In future, studies should examine whether they can generalize the study's model to SMEs in other countries. Additionally, the study adopts a small, simple, and random sampling process, which narrows the study's findings. Further studies could incorporate large sample sizes to strengthen the results. In addition, we received only one filled questionnaire from each SME, which may have resulted in common method variance bias. Future studies could assemble survey data from diverse data sources to avert this problem. Finally, future research can incorporate other marketing strategies, such as positioning and channel strategy, in the study model

\section{Acknowledgement}

We thank Ustaz Meshary Abdul Aziz A Almawash, a director of the branch of the Chamber of Commerce \& Industry in Al-Aflaj for providing us SMEs contact information. We also thank Dr. Bader Nasser Aldosari, a head of the Department of Business Administration and Accounting in College of Science and Humanity Studies in Al-Aflaj for facilitating the data collection process. The Deanship of Scientific Research at Prince Sattam Bin Abdulaziz University supported this project under the research project 2019/02/10106. 


\section{References}

Abebe, M. A., \& Angriawan, A. (2014). Organizational and competitive influences of exploration and exploitation activities in small firms. Journal of Business Research, 67(3), 339-345.

Armstrong, J. S., \& Overton, T. S. (1977). Estimating nonresponse bias in mail surveys. Journal of marketing research, 14(3), 396-402.

Aspara, J., Tikkanen, H., Pöntiskoski, E., \& Järvensivu, P. (2011). Exploration and exploitation across three resource classes: Market/customer intelligence, brands/bonds and technologies/processes. European Journal of Marketing, 45 (4), 596-630.

Aydin, R., Kwong, C. K., \& Ji, P. (2016). Coordination of the closed-loop supply chain for product line design with consideration of remanufactured products. Journal of Cleaner Production, 114, 286-298.

Bahadir, S. C., Bharadwaj, S. G., \& Srivastava, R. K. (2015). Marketing mix and brand sales in global markets: Examining the contingent role of country-market characteristics. Journal of International Business Studies, 46(5), 596-619.

Bala, R., Krishnan, V., \& Zhu, W. (2014). Distributed development and product line decisions. Production and Operations Management, 23(6), 1057-1066.

Bandeira-de-Mello, R., Fleury, M. T. L., Aveline, C. E. S., \& Gama, M. A. B. (2016). Unpacking the ambidexterity implementation process in the internationalization of emerging market multinationals. Journal of Business Research, 69(6), 2005-2017.

Beleska-Spasova, E., Glaister, K. W., \& Stride, C. (2012). Resource determinants of strategy and performance: The case of British exporters. Journal of World business, 47(4), 635-647.

Bollen, K. A. (2005). Structural Equations with Latent Variables. New Jersey: John Wiley \& Sons. DOI: https://doi.org/10.1002/9781118619179

Bonner, J. M., \& Walker Jr, O. C. (2004). Selecting influential business-to-business customers in new product development: relational embeddedness and knowledge heterogeneity considerations. Journal of Product Innovation Management, 21(3), 155-169.

Browne, M.W. \& Cudeck, R. (1993). Alternative ways of assessing model fit. In Bollen, K.A. \& Long, J.S. [Eds.] Testing structural equation models. Newbury Park, CA: Sage, 136-162.

Calantone, R. J., Tamer Cavusgil, S., Schmidt, J. B., \& Shin, G. C. (2004). Internationalization and the dynamics of product adaptation-An empirical investigation. Journal of Product Innovation Management, 21(3), 185-198.

Casey, S. R., \& Hamilton, R. T. (2014). Export performance of small firms from small countries: The case of New Zealand. Journal of International Entrepreneurship, 12(3), 254-269.

Cavusgil, S. T., \& Zou, S. (1994). Marketing strategy-performance relationship: an investigation of the empirical link in export market ventures. Journal of marketing, 58(1), 1-21.

Chavi, C. Y., Al-Husan, F. B., \& ALHussan, F. B. (2017). Relational resources for emerging markets' non-technological innovation: insights from China and Taiwan. Journal of Business \& Industrial Marketing, 32(6), 876-888.

Chen, J., Sousa, C. M., \& He, X. (2016). The determinants of export performance: a review of the literature 2006-2014. International Marketing Review, 33(5), 626-670. DOI: https://doi.org/10.1108/IMR-10-2015-0212

Chin, W. W. (2001). PLS - Graph User's Guide Version 3.0., Houston, TX: Soft Modeling Inc.

Chiva, R., Grandío, A., \& Alegre, J. (2010). Adaptive and generative learning: Implications from complexity theories. International Journal of Management Reviews, 12(2), 114-129.

Cho, H. J., \& Pucik, V. (2005). Relationship between innovativeness, quality, growth, profitability, and market value. Strategic Management Journal, 26(6), 555-575.

Day, G. S. (1994). The capabilities of market-driven organizations. Journal of marketing, 58(4), $37-52$.

Dayan, M., Zacca, R., Husain, Z., Di Benedetto, A., \& Ryan, J. C. (2016). The effect of entrepreneurial orientation, willingness to change, and development culture on new product exploration in small enterprises. Journal of Business \& Industrial Marketing, 31(4), 668-683.

De Visser, M., \& Faems, D. (2015). Exploration and exploitation within firms: the impact of CEO s' cognitive style on incremental and radical innovation performance. Creativity and Innovation Management, 24(3), 359-372.

Edmondson, A. C. (2011). Strategies for learning from failure. Harvard business review, 89(4), 48-55.

Eltantawy, R. A. (2016). The role of supply management resilience in attaining ambidexterity: a dynamic capabilities approach. Journal of Business \& Industrial Marketing, 31(1), 123-134.

Ernst, H. (2002). Success Factors of New Product Development: A Review of the Empirical Literature. International Journal of Management Reviews, 4(1), 1-40.

Fan, X., Thompson, B., \& Wang, L. (1999). Effects of sample size, estimation methods, and model specification on structural equation modeling fit indexes. Structural Equation Modeling: A Multidisciplinary Journal, 6(1), 56-83.

Faruk, O., \& Subudhi, R. N. (2019). Export Performance of SMEs: A Review of Firm-Level Controllable Determinants. Parikalpana: KIIT Journal of Management, 15(1/2), 112, DOI: https://doi.org/10.23862/kiit-parikalapana/2019/v15/i12/190177.

Fornell, C., \& Larcker, D. F. (1981). Evaluating structural equation models with unobservable variables and measurement error. Journal of marketing research, 18(1), 39-50.

Freeman, J., Styles, C., \& Lawley, M. (2012). Does firm location make a difference to the export performance of SMEs?. International Marketing Review, 29, 88-113. 
Fuchs, M., \& Köstner, M. (2016). Antecedents and consequences of firm's export marketing strategy. Management Research Review, 39 (3), 329-355.

Gabrielsson, P., Gabrielsson, M., \& Seppälä, T. (2012). Marketing strategies for foreign expansion of companies originating in small and open economies: the consequences of strategic fit and performance. Journal of International Marketing, 20(2), 25-48.

Miao, C., Du, G., Jiao, R. J., \& Zhang, T. (2017). Coordinated optimisation of platform-driven product line planning by bilevel programming. International Journal of Production Research, 55(13), 3808-3831.

Guisado-González, M., González-Blanco, J., \& Coca-Pérez, J. L. (2017). Analyzing the relationship between exploration, exploitation and organizational innovation. Journal of Knowledge Management, 21(5), 1142-1162.

Haddoud, M. Y., Nowinski, W., Jones, P., \& Newbery, R. (2019). Internal and external determinants of export performance: Insights from Algeria. Thunderbird International Business Review, 61(1), 43-60.

Hair, J. F., Black, W. C., Babin, B. J., Anderson, R. E., \& Tatham, R. (2006). Multivariate data analysis . Uppersaddle River.

He, Z. L., \& Wong, P. K. (2004). Exploration vs. exploitation: An empirical test of the ambidexterity hypothesis. Organization science, 15(4), 481-494.

Hu, L. T., \& Bentler, P. M. (1999). Cutoff criteria for fit indexes in covariance structure analysis: Conventional criteria versus new alternatives. Structural equation modeling: a multidisciplinary journal, 6(1), 1-55.

Huber, G. P., \& Power, D. J. (1985). Retrospective reports of strategic-level managers: Guidelines for increasing their accuracy. Strategic Management Journal, 6(2), 171-180.

Hughes, M., Martin, S. L., Morgan, R. E., \& Robson, M. J. (2010). Realizing product-market advantage in high-technology international new ventures: The mediating role of ambidextrous innovation. Journal of International Marketing, 18(4), $1-21$.

Hult, G. T. M., \& Ketchen Jr, D. J. (2001). Does market orientation matter?: A test of the relationship between positional advantage and performance. Strategic Management Journal, 22(9), 899-906.

Hultman, M., Katsikeas, C. S., \& Robson, M. J. (2011). Export promotion strategy and performance: the role of international experience. Journal of International Marketing, 19(4), 17-39.

Hultman, M., Robson, M. J., \& Katsikeas, C. S. (2009). Export product strategy fit and performance: An empirical investigation. Journal of International Marketing, 17(4), 1-23.

Ismail, M. D., Hamid, R. A., Senik, Z. C., Othman, A. S., \& Juhdi, N. H. (2018). SMEs' Export Performance: The Effect of Learning Orientation and Innovativeness. Jurnal Pengurusan (UKM Journal of Management), 54, 3-14. DOI: 10.17576/pengurusan-2018-54-01.

Jansen, J. J., Van Den Bosch, F. A., \& Volberda, H. W. (2006). Exploratory innovation, exploitative innovation, and performance: Effects of organizational antecedents and environmental moderators. Management science, 52(11), 16611674.

Jöreskog, K. G., Sörbom, D., \& Du Toit, S. H. C. (2001). LISREL 8: New statistical features. Scientific Software International.

Juhdi, N. H., Hong, T. S., \& Juhdi, N. (2015). Market orientation and entrepreneurial success: Mediating role of entrepreneurial learning intensity. Jurnal Pengurusan (UKM Journal of Management), 43, 27-36.

Katsikeas, C. S., Samiee, S., \& Theodosiou, M. (2006). Strategy fit and performance consequences of international marketing standardization. Strategic Management Journal, 27(9), 867-890.

Kyriakopoulos, K., \& Moorman, C. (2004). Tradeoffs in marketing exploitation and exploration strategies: The overlooked role of market orientation. International Journal of Research in Marketing, 21(3), 219-240.

Lages, L. F., Jap, S. D., \& Griffith, D. A. (2008). The role of past performance in export ventures: a short-term reactive approach. Journal of International Business Studies, 39(2), 304-325.

Lages, L. F., Silva, G., \& Styles, C. (2009). Relationship capabilities, quality, and innovation as determinants of export performance. Journal of International Marketing, 17(4), 47-70.

Laufs, K., \& Schwens, C. (2014). Foreign market entry mode choice of small and medium-sized enterprises: A systematic review and future research agenda. International Business Review, 23(6), 1109-1126.

Lejpras, A. (2019). Determinants of export performance: differences between service and manufacturing SMEs. Service Business, 13(1), 171-198.

Leonidou, L. C., Katsikeas, C. S., \& Samiee, S. (2002). Marketing strategy determinants of export performance: a metaanalysis. Journal of Business Research, 55(1), 51-67.

Leonidou, L. C., Palihawadana, D., \& Theodosiou, M. (2011). National export-promotion programs as drivers of organizational resources and capabilities: effects on strategy, competitive advantage, and performance. Journal of International Marketing, 19(2), 1-29.

Lettice, F., Roth, N., \& Forstenlechner, I. (2006). Measuring knowledge in the new product development process. International Journal of Productivity and Performance Management, 55 (3/4), 217-241. DOI: https://doi.org/10.1108/17410400610653200

Lin, Z., Yang, H., \& Demirkan, I. (2007). The performance consequences of ambidexterity in strategic alliance formations: Empirical investigation and computational theorizing. Management science, 53(10), 1645-1658. 
Lisboa, A., Skarmeas, D., \& Lages, C. (2011). Entrepreneurial orientation, exploitative and explorative capabilities, and performance outcomes in export markets: A resource-based approach. Industrial marketing management, 40(8), 12741284.

Loch, C., Stein, L., \& Terwiesch, C. (1996). Measuring development performance in the electronics industry. Journal of Product Innovation and Management, 13(1), 3-20.

Lu Jin, J., Zhou, K. Z., \& Wang, Y. (2016). Exploitation and exploration in international joint ventures: Moderating effects of partner control imbalance and product similarity. Journal of International Marketing, 24(4), 20-38.

Lukas, B. A., Whitwell, G. J., \& Hill, P. (2007). Export planning orientation and its antecedents: Evidence from exporting IT products. Journal of Business Research, 60(12), 1282-1289.

MacKinnon, D. P., Lockwood, C. M., Hoffman, J. M., West, S. G., \& Sheets, V. (2002). A comparison of methods to test mediation and other intervening variable effects. Psychological methods, 7(1), 83.

Madsen, P. M., \& Desai, V. (2010). Failing to learn? The effects of failure and success on organizational learning in the global orbital launch vehicle industry. Academy of management journal, 53(3), 451-476.

March, J. G. (1991). Exploration and exploitation in organizational learning. Organization science, 2(1), 71-87.

Martini, A., Laugen, B. T., Gastaldi, L., \& Corso, M. (2013). Continuous innovation: towards a paradoxical, ambidextrous combination of exploration and exploitation. International Journal of Technology Management, 61(1), 1-22.

Menon, A., Bharadwaj, S. G., Adidam, P. T., \& Edison, S. W. (1999). Antecedents and consequences of marketing strategy making: a model and a test. Journal of marketing, 63(2), 18-40.

Münch, Jurgen, Stephan Trieflinger and Dominic Lang, (2019) "Product Roadmap - From Vision to Reality: A Systematic Literature Review," 2019 IEEE International Conference on Engineering, Technology and Innovation (ICE/ITMC), Valbonne Sophia-Antipolis, France, 1-8. doi: 10.1109/ICE.2019.8792654.

Nunnally, J. C. (1994). Psychometric theory 3E. Tata McGraw-hill education.

Nuseir, M. T. (2016). Analyzing the Influence of International Entrepreneurship on the SMEs Exporting Performance Using Structural Equation Model: An Empirical Study in Jordan. International Journal of Business and Management, 11(2), 153-163.

Podsakoff, P. M., MacKenzie, S. B., Lee, J. Y., \& Podsakoff, N. P. (2003). Common method biases in behavioral research: a critical review of the literature and recommended remedies. Journal of applied psychology, 88(5), 879.

Preacher, K. J., \& Hayes, A.F. (2008), Contemporary Approaches to Assessing Mediation in Communication Research. In A. F. Hayes, M. D. Slater, \& L. B. Snyder (Eds.), The Sage sourcebook of advanced data analysis methods for communication research (pp. 13-54). Thousand Oaks, CA: Sage.

Rossiter, J. R. (2002). The C-OAR-SE procedure for scale development in marketing. International Journal of Research in Marketing, 19(4), 305-335.

Samiee, S., \& Chirapanda, S. (2019). International marketing strategy in emerging-market exporting firms. Journal of International Marketing, 27(1), 20-37.

Santos-Vijande, M. L., López-Sánchez, J. Á., \& Trespalacios, J. A. (2012). How organizational learning affects a firm's flexibility, competitive strategy, and performance. Journal of business research, 65(8), 1079-1089.

Sheremata, W. A. (2000). Centrifugal and centripetal forces in radical new product development under time pressure. Academy of management review, 25(2), 389-408.

Shi, X., Su, L., \& Cui, A. P. (2020). A meta-analytic study on exploration and exploitation. Journal of Business \& Industrial Marketing, 35(1), 97-115. DOI: https://doi.org/10.1108/JBIM-03-2019-0119

Sinha, S. (2015). The exploration-exploitation dilemma: a review in the context of managing growth of new ventures. Vikalpa, 40(3), 313-323.

Song, X. M., \& Parry, M. E. (1997). A cross-national comparative study of new product development processes: Japan and the United States. Journal of marketing, 61(2), 1-18.

Sousa, C. M., \& Tan, Q. (2015). Exit from a foreign market: Do poor performance, strategic fit, cultural distance, and international experience matter?. Journal of International Marketing, 23(4), 84-104.

Stouraitis, V., Harun, M. H. M., \& Kyritsis, M. (2017). Motivators of SME initial export choice and the European Union regional effect in manufacturing. International Journal of Entrepreneurial Behavior \& Research, 23(1), 35-55.

Syamil, A., Doll, W. J., \& Apigian, C. H. (2004). Process performance in product development: measures and impacts. European Journal of Innovation Management, 7(3), 205-217. DOI: https://doi.org/10.1108/14601060410549892

Tan, Q., \& Sousa, C. M. (2011). Research on export pricing: Still moving toward maturity. Journal of International Marketing, 19(3), 1-35.

Tamayo-Torres, J., Moreno, A.R., \& Montes, F.J.L. (2011). The Influence of Manufacturing Flexibility on the Interplay between Exploration and Exploitation: The Effects of Organizational Learning and the Environment. International Journal of Production Research, Taylor \& Francis, 49 (20), 6175-6198. DOI: doi.org/10.1080/00207543.2010.518989

Tushman, M. L., \& O'Reilly, C.A. (1996). Ambidextrous Organizations: Managing Evolutionary and Revolutionary Change. California Management Review, 38(4) 8-30.

Uner, M. M., Kocak, A., Cavusgil, E., \& Cavusgil, S.T. (2013). Do Barriers to Export Vary for Born Globals and Across Stages of Internationalization? An Empirical Inquiry in the Emerging Market of Turkey. International Business Review, 22(5), 800-813. DOI: doi.org/10.1016/j.ibusrev.2012.12.005

Uotila, J., Maula, M., Keil, T., \& Zahra, S.A. (2009). Exploration, Exploitation, and Financial Performance: Analysis of S\&P 500 Corporations. Strategic Management Journal, 30 (2), 221-231. DOI: 10.1002/smj.738 
Ural, T. (2009). The Effects of Relationship Quality on Export Performance: A Classification of Small and Medium-sized Turkish Exporting Firms Operating in Single Export-market Ventures. European Journal of Marketing, 43(1/2), 139168.

Vahlne, J.-E., \& Johanson, J. (2017). From Internationalization to Evolution: The Upsala Model at 40 Years. Journal of International Business Studies, 48(9), 1087-1102.

Venkatraman, N. (1990). Performance Implications of Strategic Coalignment: A Methodological Perspective. Journal of Management Studies, 27(1), 19-41.

Venkatraman, N., \& Prescott, J.E. (1990). Environment-Strategy Coalignment: An Empirical Test of Its Performance Implications. Strategic Management Journal, 11 (1), 1-23.

Wei, Y. S., Samiee, S., \& Lee, R. (2014). The Influence of Organic Organizational Cultures, Market Responsiveness, and Product Strategy on Firm Performance in an Emerging Market. Journal of the Academy of Marketing Science, 42 (1), 49-70.

Westjohn, S. A., \& Magnusson, P. (2017). Export Performance: A Focus on Discretionary Adaptation. Journal of International Marketing, 25(4), 70-88. DOI: 10.1509/jim.16.0114

Wheeler, C., Ibeh, K., \& Dimitratos, P. (2008). UK Export Performance Research Review and Implications. International Small Business Journal, 26 (2), 207-239.

Xie, Z., \& Li, J. (2018). Exporting and Innovating Among Emerging Market Firms: The Moderating Role of Institutional Development. Journal of International Business Studies, 49(2), 222-245.

Zou, S., \& Cavusgil, T. (2002). The GMS: A Broad Conceptualization of Global Marketing Strategy and Its Effect on Firm Performance. Journal of Marketing, 66(4), 40-56. doi:10.1509/jmkg.66.4.40.18519

Zou, S., Charles R. Taylor, \& Osland, G.E. (1998). The EXPERF Scale: A Cross-National Generalized Export Performance Measure. Journal of International Marketing, 6(3), 37-58. https:// doi.org/10.1177/1069031x9800600307

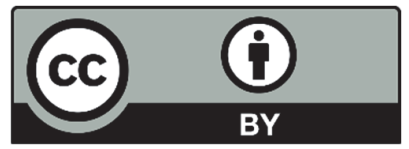

(C) 2021 by the authors; licensee Growing Science, Canada. This is an open access article distributed under the terms and conditions of the Creative Commons Attribution (CC-BY) license (http://creativecommons.org/licenses/by/4.0/). 